\title{
Study of the mechanical and metallurgical properties of sintered steels for valve seat inserts application
}

\author{
Gomes, M. P. ${ }^{1}$; Santos, I. P. ${ }^{1}$; Mucsi, C. S. ${ }^{1}$; Colosio, M. A2; Rossi, J. L. ${ }^{1}$ \\ ${ }^{1}$ Instituto de Pesquisas Energéticas e Nucleares, IPEN - CNEN, São Paulo, SP, Brazil. \\ ${ }^{2}$ General Motors do Brasil, São Caetano do Sul, SP, Brazil.
}

*e-mail: m_gomes@outlook.com

\begin{abstract}
The aim of this work was to study the valve seat insert (VSI) produced with three different alloys (mainly modified from the original AISI M3/2, M2 and D2 high-speed steels) from the mechanical and metallurgical point of view. These alloys modifications were intended as an alternative to replace cobalt and lead used in the original alloy due to their high cost and toxicological effect respectively. Such alloys have been developed for internal combustion engines VSI manufacture. The VSI studied in this work was previously produced by the powder metallurgy (P/M) route. The VSI production was performed using a uniaxial hydraulic press and a belt conveyor furnace. The VSI was submitted to metallic infiltration during the sintering process using copper as filler. The studies were performed according to standardized apparent density (ASTM C 373-88), apparent hardness (ASTM E 92-82) and radial crush strength (MPIF Standard 35) tests. The VSI produced with $\mathrm{M} 3 / 2$ alloy proved to be more advantageous considering the highest values obtained in the apparent hardness and radial crush strength tests.
\end{abstract}

Keywords: powder metallurgy, characterization, valve seat insert, high-speed steel.

\section{Resumo}

O objetivo deste trabalho foi estudar o inserto para assento de válvula (do inglês VSI - Valve Seat Insert) produzido com três ligas diferentes (modificadas principalmente das ligas originais de aço rápido AISI M3/2, M2 e D2) do ponto de vista mecânico e metalúrgico. As modificações destas ligas foram pretendidas como uma alternativa para substituir o cobalto e o chumbo usados na liga original, devido ao seu custo elevado e efeito toxicológico respectivamente. Tais ligas têm sido desenvolvidas para a manufatura de VSI utilizados em motores à combustão interna. O VSI estudado neste trabalho foi produzido pela rota da metalurgia do pó (M/P). Este processo foi realizado utilizando-se uma prensa hidráulica de compactação e um forno contínuo de esteira. Os VSI foram submetidos a infiltração metálica durante a etapa de sinterização utilizando cobre como infiltrante. Os estudos foram determinados de acordo com testes padronizados, sendo eles: densidade aparente (ASTM C 373-88), dureza aparente (ASTM E 92-82) e resistência à ruptura radial (MPIF padrão 35). Os VS/ produzidos com a liga $\mathrm{M} 3 / 2$ provaram ser mais vantajosos considerando-se os valores obtidos nos ensaios de dureza aparente e resistência à ruptura radial.

Palavras-chave: metalurgia do pó, caracterização, inserto de assento de válvula, aço rápido.

\section{Introduction}

The powder metallurgy $(\mathrm{P} / \mathrm{M})$ is a near-net shape manufacturing process that combines the features of shape-making technology for powder compaction with the development of final material and design properties (physical and mechanical) during subsequent densification or consolidation processes (e.g., sintering) [1].

Automobile engines have undergone substantial changes, which have resulted in increased performance, reduced fuel consumption and environmental impact. The use of $\mathrm{P} / \mathrm{M}$ components have improved engine performance, as well as reducing costs [2]. The mechanical set responsible for sealing the combustion chamber is constituted of valve and insert, as shown in Fig. 1.1.

The valve seat insert (VSI) studied in the present work was produced with three different alloys, modified from the original AISI M3/2, M2 and D2. These alloys modifications were intended as an alternative to replace cobalt and lead used in the original alloy due to their high cost and toxicological effect respectively. The purpose of this work was to study the VSI mechanical and metallurgical properties. These properties were determined according to standardized apparent density 


\section{Encontro Científico de Física Aplicada}

(ASTM C 373-88), apparent hardness (ASTM E 92-82) and radial crush strength (MPIF Standard 35 ) tests.

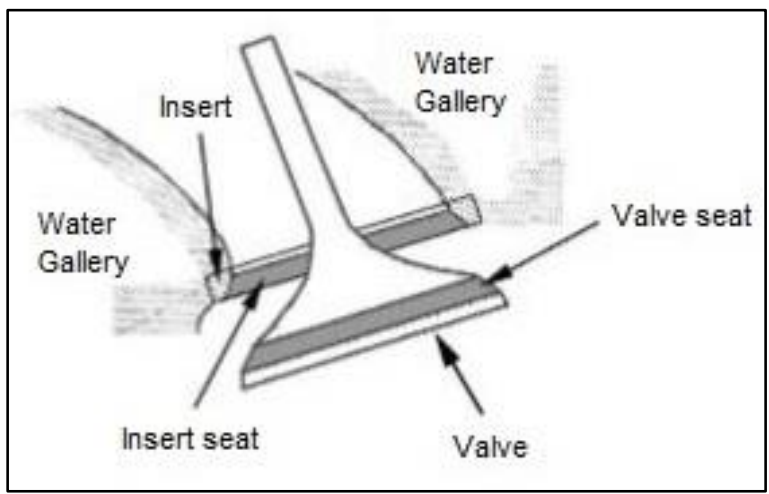

Figure 1.1: Drawing indicating the valve and insert position in an internal combustion engine (adapted from [3]).

These components represent one of the biggest challenge from the metallurgical point of view when the aim is to increase engine's performance and reduce its manufacturing costs. The valve and insert operates under severe conditions, and there are two critical situations corresponding to the air/fuel mixture intake and exhaust. The worst case occurs in the exhaust stroke when the temperature at the valve seat can heat up to $700^{\circ} \mathrm{C}$, and at the insert seat until $350^{\circ} \mathrm{C}$ [3].

\section{Experimental methods}

\subsection{Inserts manufacture}

All the powders were mixed, except copper. The copper was compacted separately and added by metallic infiltration during the inserts sintering process, as shown in Fig. 2.1. The inserts were compacted in a uniaxial hydraulic press at $700 \mathrm{MPa}$. The inserts sintering process have been performed in a continuous industrial belt conveyor furnace, in solid state, under a controlled atmosphere constituted of $70 \%$ hydrogen and $30 \%$ nitrogen. The inserts were submitted to a preheat process for 35 minutes at $600 \stackrel{\circ}{\circ}$ to ensure the whole $\mathrm{Zn}$ stearate elimination, and then the inserts were sintered at $1,150 \stackrel{\circ}{ } \mathrm{C}$ during 40 minutes [4].
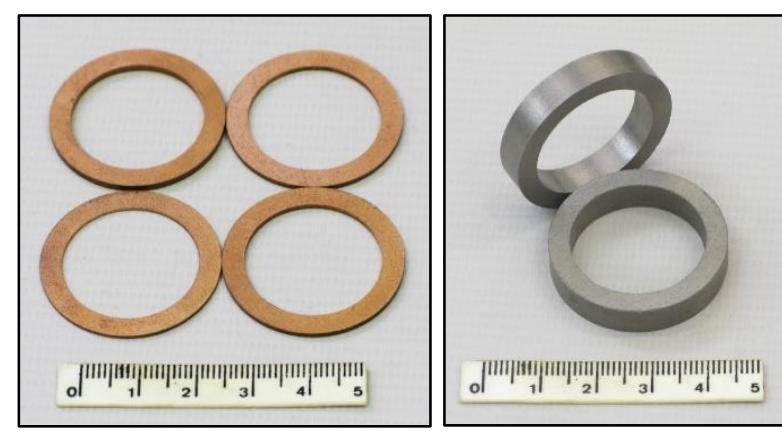

Figure 2.1: Copper rings and inserts before sintering process respectively.

\subsection{Inserts characterization}

\subsubsection{Apparent density}

The apparent density was determined immersing the inserts into water, in agreement with the standard ASTM C 373-88 [5]. The inserts were boiled in distilled water for one hour, and soaked for additional twenty-four hours. The specimen immersed in water' mass, and specimen water impregnated' mass were measured respectively. The specimen dry mass was determined after heating it in an oven at $150^{\circ} \mathrm{C}$ for one hour and a half, followed by cooling in a desiccator. All the masses were measured in an analytical balance with a precision of $0.0001 \mathrm{~g}$. With the values obtained, such as: dry mass (D), wet mass $(W)$, immersed mass (I) and water density ( $\rho)$ the following equation (1) was used to determine the inserts apparent density (B).

$$
B=\left[\frac{D}{(W-I)}\right] \cdot \rho
$$

\subsubsection{Apparent hardness}

The standard test for the inserts apparent hardness determination was realized in Vickers $\left(\mathrm{HV}_{100}\right)$ scale, according to the standard ASTM E 92-82 [6]. During the test was used a force of $100 \mathrm{kgf}$ and a square-based pyramidal diamond (indenter) with face angles of $136^{\circ} \pm$ $30 \mathrm{~min}$. According to the standard test is necessary to use the follow equation (2) to determine the specimen apparent hardness.

$$
H V=[2 \cdot P \cdot \sin (\alpha / 2)] / d^{2}
$$

Where:

$P=$ force $(\mathrm{kgf})$;

$d=$ mean diagonal of impression $(\mathrm{mm})$ and

$\alpha=$ face angle of diamond $=136^{\circ}$.

\subsubsection{Radial crush strength}

This standard test was performed according to MPIF Standard 35 [7]. This test consists of compressing radially the insert until its first crack. The inserts' radial crush strength resistance were determined with the following equation (3).

$$
K=P .\left(\frac{D-e}{L . e^{2}}\right)
$$

Where:

$K=$ Radial crush strength (MPa);

$D=$ Insert's external diameter $(\mathrm{mm})$;

$e=$ Insert's wall thickness $(\mathrm{mm})$;

$L=$ Insert's height $(\mathrm{mm})$ and

$P=$ Maximum load supported by the insert until the first $\operatorname{crack}(\mathrm{N})$. 


\section{Results}

Post sintering process, some inserts were analyzed to check the metallic infiltration and if there was no visible defects as crack, missing parts and so on. Thereby, the inserts mechanical and metallurgical properties were determined. It was determined according to standardized tests, established by ASTM and MPIF. The graphics bellow show the results obtained during the apparent density (Fig. 3.1), apparent hardness (Fig. 3.2) and radial crush strength (Fig. 3.3) tests with its standard deviation bar.

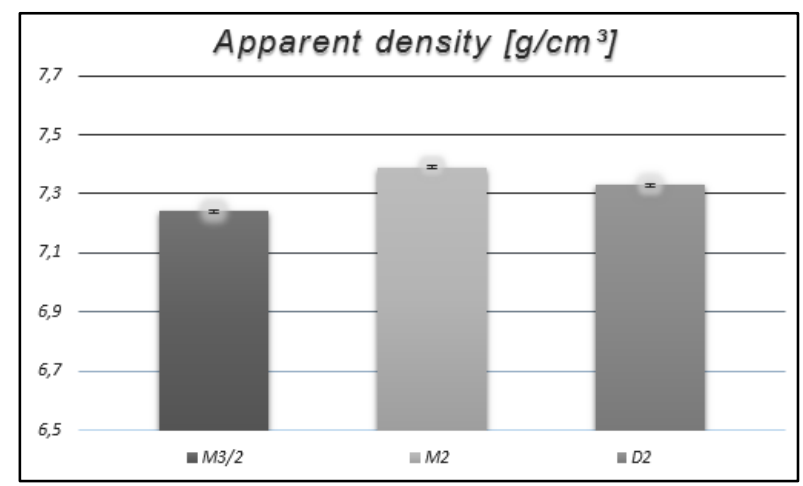

Figure 3.1: Graphic showing the results obtained during the apparent density test.

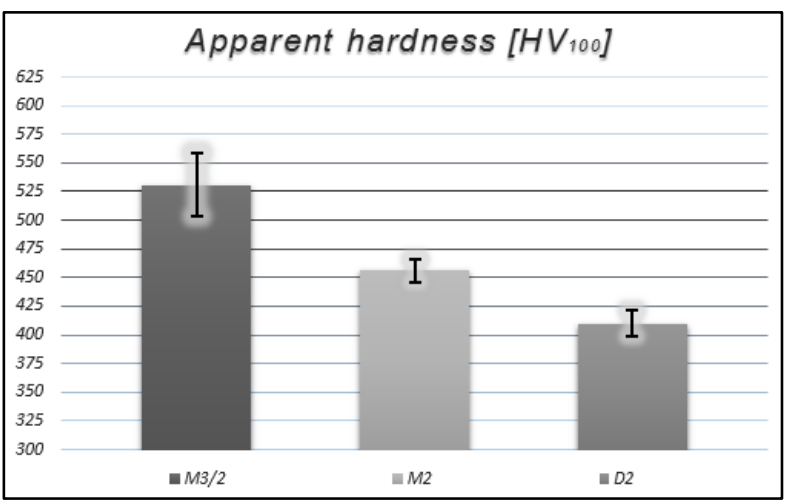

Figure 3.2: Graphic showing the results obtained during the apparent hardness test.

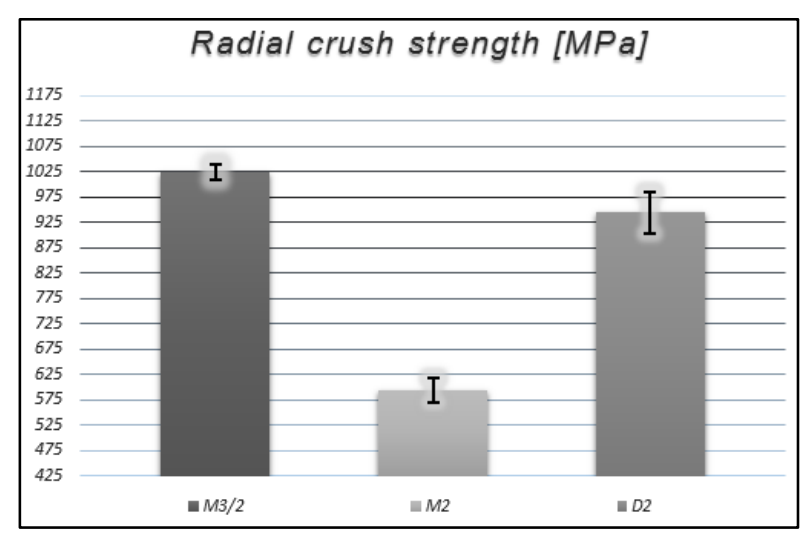

Figure 3.3: Graphic showing the results obtained for three different alloys during the radial crush strength test.
The following table is a resume of the results obtained in the graphics above.

Table 3.1 - Standardized tests results for the three different alloys studied.

\begin{tabular}{|cccc|}
\hline Alloy $\backslash$ Property & $\begin{array}{c}\text { Density } \\
\left(\mathrm{g} / \mathrm{cm}^{\mathbf{3}}\right)\end{array}$ & $\begin{array}{c}\text { Hardness } \\
\text { (HV 100) }\end{array}$ & $\begin{array}{c}\text { Radial crush } \\
\text { strength (Mpa) }\end{array}$ \\
\hline M3/2 & $7.24 \pm 0,01$ & $531 \pm 56$ & $1,024 \pm 32$ \\
\hline M2 & $7.39 \pm 0,01$ & $456 \pm 21$ & $595 \pm 48$ \\
\hline D2 & $7.33 \pm 0,01$ & $410 \pm 22$ & $945 \pm 81$ \\
\hline
\end{tabular}

\section{Conclusion}

The inserts produced with the M3/2 alloy showed best results in terms of apparent hardness and radial crush strength. The higher hardness ensure a longer working life due to the critical friction situation between the insert seat and valve seat.

On the other hand, the inserts manufactured with the D2 alloy showed lower apparent hardness. It is a positive aspect because the inserts must be machined, and the tool wear will be much lower.

\section{References}

[1] ASM International Handbook Committee, Metals Handbook Vol. 7. Powder Metal Technologies and Applications. ASM International, $10^{\text {th }}$ ed., 1999 (electronic version).

[2] CHANG, I.; ZHAO, Y. Advances in Powder Metallurgy: Properties, processing and applications Woodhead Publishing, UK, 2013.

[3] Grupo Setorial de Metalurgia do Pó. A metalurgia do Pó: alternativa econômica com menor impacto ambiental, Metallum Eventos Técnicos, $1^{\text {a }}$ ed., 2009.

[4] SANTOS, I. P. Processamento e caracterização de aços sinterizados para uso em insertos de assentos de válvulas. 2014. Dissertação (Mestrado) - Instituto de Pesquisas Energéticas e Nucleares, IPEN-CNEN/SP, São Paulo. Online at: <http://www.teses.usp.br/teses/dis poniveis/85/85134/tde-28012015-150337/publico/2014 SantosProcessamento.pdf> Accessed on: December $22^{\text {th }} 2015$.

[5] ASTM American Society for Testing and Materials. Standard Test Method for: Water Absorption, Bulk Density, Apparent porosity and Apparent Specific Gravity of Fired Whiteware Products. ASTM C 37388, 1999.

[6] ASTM American Society for Testing and Materials. Standard Test Method for: Vickers Hardness of Metallic Materials. ASTM E 92-82, 2003.

[7] MPIF Metal Powder Industries Federation. Method for Determination of Crush Radial Strength. MPIF Standard 35, 1965. 